\title{
SERPINC1 Gene
}

National Cancer Institute

\section{Source}

National Cancer Institute. SERPINC1 Gene. NCI Thesaurus. Code C104681.

This gene is involved in the regulation of the coagulation cascade. 